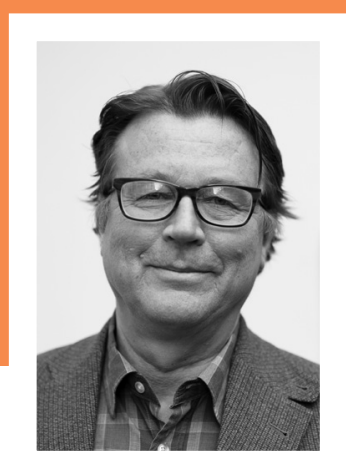

\title{
EIKÖ AIKUISKOULUTUS KIINNOSTA?
}

$\mathrm{K}$ KUN TILASTOKESKUS JULKISTI tammikuussa ennakkotietoja aikuiskoulutukseen osallistumisesta Suomessa vuonna 2017, tulokset jäivät mediassa vähälle huomiolle. Tiedot perustuvat aikuisväestön haastatteluihin, joita Tilastokeskus on tehnyt toistuvasti vuodesta 1980 alkaen. Tutkimus on toistettu noin viiden vuoden välein, ja uusin tiedonkeruu on seitsemäs laatuaan. Tutkimusta varten haastateltiin 3400 Suomessa pysyvästi asuvaa kansalaista. Haastateltavat olivat 18-69-vuotiaita.

Ottaen huomioon, millaisesta ponnistuksesta Aikuiskoulutustutkimus 2017 -tutkimuksen (AKU 2017) tiedonkeruussa on kysymys, median vähäinen kiinnostus ihmetyttää. Onko aikuisväestön osallistuminen koulutukseen menettänyt yleisemminkin kiinnostavuuttaan? Vai onko siitä tullut niin tavallista, ettei sillä ole uutisarvoa? Sen enempää Yle kuin Helsingin Sanomatkaan eivät noteeranneet tulosten julkistusta.

AIKUISKOULUTUKSEEN OSALLISTUMINEN kasvoi koko 1980 luvun ajan, kunnes tyssäsi 1990-luvun talouslamaan. Vajaa puolet aikuisista osallistui koulutukseen vuoden aikana. Lama-aikana erityisesti työnantajien järjestämä koulutus väheni reippaasti.

Uusi osallistumishuippu ajoittuu vuosituhannen vaihteeseen, jonka jälkeen niin miesten kuin naistenkin osallistumisasteet ovat pienentyneet. Vuonna
2017 naisista osallistui koulutukseen 54 prosenttia ja miehistä 43 prosenttia. Väestöön yleistettynä prosentit tarkoittavat noin 1,6 miljoonaa kansalaista. Nykyiset osallistumisasteet ovat melko tarkkaan samat kuin lähes kolme vuosikymmentä aiemmin vuonna 1990. Sukupuolten välinen ero kymmenisen prosenttiyksikköä.

Vuoden 2000 mittauksesta alkanut laskeva trendi on uutisen arvoinen, mutta muuten moni asia aikuiskoulutukseen osallistumisessa on säilynyt ennallaan. Työnantajan kustantama henkilöstökoulutus on edelleen se koulutusmuoto, jonka ansiosta Suomen osallistumisasteet ovat kansainvälisissä vertailuissa niin korkeat. Toki työhön ja ammattiin liittyvä koulutus on muutenkin yleisin koulutustyyppi Suomessa. Noin 1,2 miljoonaa aikuista eli suunnilleen puolet työvoimaan kuuluvista osallistuu koulutukseen työhön liittyvien syiden vuoksi. Yleisintä osallistuminen on nuorten aikuisten eli 25-34-vuotiaiden ikäryhmässä.

NAISET OSALLISTUVAT niin henkilöstökoulutukseen kuin muuhunkin ammatilliseen aikuiskoulutukseen miehiä useammin. Jo kauan aikaa naiset ovat olleet selvänä enemmistönä erilaisissa harrastustavoitteisissa koulutusmuodoissa, esimerkiksi vapaan sivistystyön oppilaitoksissa kansalaisopistoissa ja kansanopistoissa. Naisten osallistumisaste vapaan sivistystyön koulutuksiin on kaksinkertainen miehiin verrattuna. 
Suurin muutos osallistumisessa sisältyy juuri harrastustavoitteisiin opintoihin. Vuodesta 1990 lähtien naisten osallistumisaste on ollut yleensä 26 prosenttia. Vuonna se näyttää kutistuneen selvästi, 19 prosenttiin. Miehistä harrastusopintoihin osallistuu yhdeksän prosenttia. Naisten osallistumisen väheneminen on merkittävin muutos, joka vapaan sivistystyön osallistumisasteissa on tapahtunut noin 30 vuoteen. Vasta myöhemmin ilmestyvät tarkemmat analyysit kertovat, mistä tässä on kysymys.

AIKASARJOISTA VOI PÄÄTELLÄ osallistumisaktiivisuuden vähentyneet ihan tuntuvasti. AKU 2017 -tutkimuksen paljastamia muutoksia tuskin voi selittää satunnaisvaihtelulla. Tulokset viestivät jotain todellisesta. Onko vapaa sivistystyö menettänyt kiinnostavuuttaan vai ovatko ihmiset vain hankkineet uusia harrastuksia? Miten osallistumisaktiivisuus on muuttunut sosioekonomisissa ryhmissä: ovatko jotkin väestöryhmät erityisesti kaikonneet vapaan sivistystyön piiristä?

Koulutuksen kysyntään vaikuttaa yksilöllisten halujen lisäksi toki tarjonta. Nyt tarvittaisiinkin alueellisesti tai paikallisesti tehtyjä analyysejä kysynnän ja tarjonnan kohtaamisesta. Kansalaisten yleinen aktiivisuus ei ole muuttunut miksikään, se vain on ehkä muuttanut muotoaan.

Pääministeri Juha Sipilän (kesk.) hallituksen aktiivimalliksi nimeämä työttömien sääntely on nostattanut varsinaisen kritiikin hyökyaallon. Tunti- ja euromääriä myöten hallitus haluaa määrittää, mikä on työttömän aktiivisuutta. Aktiivisuuden täytyy olla rahavälitteistä tai sen on kanavoiduttava valtion järjestämiin toimenpiteisiin, vaikka osallistuminen ei auttaisi työtöntä itseään lainkaan.
Tästä keväästä lähtien työttömiä kohdellaan epätasa-arvoisesti ammattialoittain ja alueittain, kun kaikki eivät voi täyttää "aktiivisuuden" kriteereitä.

SÄÄNTELYYN SISÄLLYTETYT SANKTIOT eivät sovi nyky-yhteiskuntaan. Pakotettu aktiivisuus ei ole aktiivisuutta lainkaan. Vielä viime vuonna työtön on voinut olla omaehtoisesti aktiivinen käymällä vaikkapa kansalaisopiston kursseilla. Mutta tänä vuonna se ei ole enää oikeaa aktiivisuutta. Työttömän käyttäytymistä sääntelevät kriteerit ovat absurdeja, ellei osallistumista esimerkiksi vapaaehtoistyöhön tai vapaan sivistystyön opintoihin katsota aktiivisuudeksi.

\section{Heikki Silvennoinen}

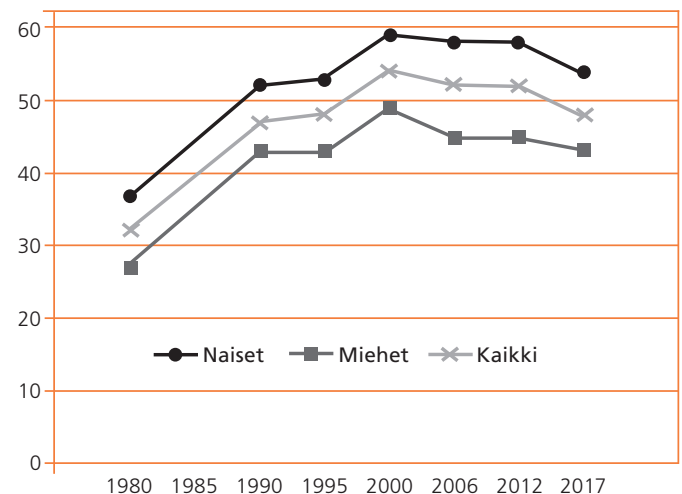

Kuvio 1. Aikuiskoulutukseen osallistuminen vuosina 1980-2017 Suomessa: osallistuneiden osuus 18-64-vuotiaasta väestöstä sukupuolen mukaan (\%). Lähde: Tilastokeskus. 